\title{
SECRETION OF $\alpha$-AMYLASE FROM PAROTID LOBULES OF YOUNG AND OLD RATS
}

\author{
Sun-Kee Kim ${ }^{1}$, Debby W. Calkins ${ }^{2}$ and Paul A. Weinhold ${ }^{3}$ \\ Research Service, V.A. Medical Center ${ }^{1.3}$, Ann Arbor, Michigan 48105, and Departments of Anatomy ${ }^{1.2}$ and \\ Biochemistry ${ }^{3}$, The University of Michigan Medical School
}

(Received 2 February 1982)

\begin{abstract}
The rate of release of a secretory enzyme, $\alpha$-amylase, from the parotid lobules of 2 and 24 month old rats has been compared to determine whether the secretory activity of the cells change during aging. Upon incubation in the presence of a secretogogue, isoproterenol $\left(10^{-3} \mathrm{M}\right)$, about the same proportions of the glandular $\alpha$-amylase are released at about the same rate from these lobules. The isoproterenol-stimulated release of the enzyme is inhibited nearly completely by preincubating the lobules with propranolol $\left(10^{-5} \mathrm{M}\right)$ in both age groups, indicating that the enzyme secretion occurs through the stimulation of $\beta$-receptors. When viewed in the electron microscope, the cell membranes bordering the secretory lumen in isoproterenol-incubated lobules reveal festooned appearances which suggest that the enzyme release occurs by means of exocytosis. These observations indicate that the ability of the parotid cells to release secretory products through the $\beta$-receptor mediation does not significantly change with increasing age.
\end{abstract}

\section{INTRODUCTION}

SOME ASPECTS of the salivary gland function in humans undergo changes with increasing age. The rate of basal salivary flow, as well as the stimulated secretion of saliva, decreases with age (Bertram, 1967; Meyer and Necheles, 1940). Also, the content of amylase in mixed saliva is reduced in elderly persons (Chilla, et al., 1974; Meyer and Necheles, 1940; Meyer, et al. 1937), indicating the reduction in the secretory protein content of the saliva.

These reductions in the salivary flow and the protein content suggest that the processes of synthesis and/or release of secretory proteins decline with age. In our previous studies with parotid glands of the rat, we have demonstrated that the cellular level of protein synthesis progressively declines with increasing age as determined by the reduction in the rate of incorporation of radioactive amino acids into the acid-insoluble proteins (Kim, 1981, Kim, et al., 1980; 1981) or secretory proteins (Kim, et al., 1982) of the gland. Furthermore, this decline seems to reflect specific changes in the synthesis of proteins in this gland, and not changes in the cellular metabolic activity with aging (Kim, et al., 1980).

Previous studies have shown that the processes of synthesis and release of secretory proteins are interrelated in exocrine secretory cells. In pancrease and parotid glands of rats,

Address Correspondence to: Dr. S.K. Kim, Research Service, V.A. Medical Center, Ann Arbor, Michigan 48105 . 
the rate of protein synthesis increases following the stimulated secretion of glandular content (Grand and Gross, 1969; Lillie and Han, 1973; Sreebny, et al., 1971). Then, the agerelated reduction in the rate of protein synthesis in parotid glands of rats might be related to the decline in the secretory activity of the glandular cells.

The secretory activity of the salivary gland is controlled largely by the autonomic nervous system (Schneyer and Hall, 1967), and the release of secretory proteins is induced by epinephrine (Bdolah, et al., 1964; Bdolah and Schramm, 1965). The release of amylase from parotid glands of the rat is strongly stimulated by agents with $\beta$-agonist activity such as isoproterenol (IPR) and the catecholamines (Bdolah, et al., 1964; Nelson and Stouffer, 1972; Butcher et al., 1975). Following a single injection of IPR, a near complete discharge of $\alpha$-amylase from parotid glands of the rat takes place within 2 hours (Malamud, 1972; Lillie and Han, 1973).

The release of $\alpha$-amylase can be induced also by incubating parotid gland slices or lobules in the presence of IPR (Castle, et al., 1972; Kusek, 1979). The process of amylase secretion through $\beta$-receptor activation seems to involve cyclic AMP (Babad, et al., 1967; Bdolah and Schramm, 1965; Butcher and Goldman, 1974), and can be prevented with $\beta$-adrenergic blocker propranolol (Castle, et al., 1972; Kusek, 1979; Malamud, 1972).

This study was undertaken to determine whether there are age-related changes which affect the ability of parotid gland cells to release secretory proteins. This was done by comparing the cellular level of $\alpha$-amylase and profile of release of the enzyme from parotid lobules of 2 and 24 month old rats upon incubation with IPR. In order to determine whether the IPR-stimulated release of $\alpha$-amylase in the older rats also occurs by means of exocytosis as in young rats (Amsterdam, et al., 1909), morphological observations of the lobules were made at various times during the incubation. In addition, some lobules were preincubated in the presence of propranolol to examine whether the IPR-stimulated release of the enzyme is inhibited by a $\beta$-blocker.

\title{
MATERIALS AND METHODS
}

\begin{abstract}
Animals
Male, Sprague-Dawley rats of 2 and 24 months of age were used and obtained from Charles River Breeding Laboratories in Portage, Michigan. The 24 month old rats came from the colony of retired breeders which were grouped into cohorts between 10 and 12 months of age. Therefore, the rats in this age group ranged from 23 to 25 months. All rats were maintained behind a barrier containment facility and were screened regularly for known pathogens. These rats are also free of immunological titers for sialodacryoadenitis (SDA) virus which affects the submandibular and parotid glands of rats and is widespread in many commercial stocks of rats. Rats were fed ad libitum and were housed under controlled light and dark conditions for more than three days before using them for experiments. Food was withheld for about 16 hours before beginning an experiment, but rats were allowed access to drinking water. Rats were killed by cervical dislocation.
\end{abstract}

\section{IRP-stimulated release of $\alpha$-amylase}

After killing the rats, the parotid glands were removed and immersed in Eagle's Minimum Essential Medium (MEM) that had been warmed to $37^{\circ} \mathrm{C}$ (Babad et al., 1967). The medium was gassed with a mixture of 95 percent $\mathrm{O}_{2}$ and 5 percent $\mathrm{CO}_{2}$. The removed glands were cleaned of connective tissue, blood vessels, nerves and large ducts in the central region. Parotid lobules were isolated manually with Dumont \#5 forceps with fine tips under a dissecting microscope. During the lobule separation, the gas mixture was continuously bubbled into the medium through a thin glass tubing. Lobules from at least 2 rats were pooled and preincubated in $15 \mathrm{ml}$ of gassed MEM at $37^{\circ} \mathrm{C}$ for 15 minutes to wash out amylase from the ducts or the damaged cells. The lobules were placed in a 50 $\mathrm{ml}$ flask containing $10 \mathrm{ml}$ of MEM supplemented with desired concentrations of IPR (dl-isoproterenol, City Chemical, New York) and incubated at $37^{\circ} \mathrm{C}$ in a water bath which was continuously agitated at $80 \mathrm{cycles} / \mathrm{min}$. During incubation, $50 \mu \mathrm{l}$ of fresh IPR solution was added to each flask every 30 minutes to replace used up and oxidized IPR (Castle et al., 1972). 
At various time periods, $1 \mathrm{ml}$ of medium was withdrawn for amylase assay and replaced with $1 \mathrm{ml}$ of fresh MEM. A small amount of IPR solution was also added to the medium to make up for the secretogogue depleted by medium removal. During this experiment, a fresh IPR stock solution was prepared every hour to eliminate errors in the drug concentration due to oxidation. For controls, the lobules were incubated in MEM with an equal volume of distilled water replacing IPR.

To determine the effect of a $\beta$-blocker on the IPR-stimulated release of $\alpha$-amylase, the lobules were preincubated for $30 \mathrm{~min}$. in the medium containing dl-propranolol hydrochloride (Ayerst, New York). The control lobules were incubated in the medium with the same amount of distilled water replacing propranolol. Following preincubation, the lobules were further incubated in MEM supplemented with $10^{-5} \mathrm{M}$ IPR. The incubation medium also contained the same concentration of propranolol as in the preincubation medium. The control lobules were divided into 2 groups following preincubation with propranolol. One group was incubated in MEM supplemented with $10^{-5} \mathrm{M}$ of IPR and the other group in MEM containing an equal volume of distilled water. At the end of various time intervals, $1 \mathrm{ml}$ of medium was withdrawn for amylase assay. The medium was replaced each time, and a small amount of IPR and propranolol was added to the medium to bring up the concentrations to the original levels.

\section{Assays of Amylase Release}

The assay of $\alpha$-amylase activity was done by using the Roche Amylochrome assay kit (Roche Diagnostics, Nutley, N.J.) as described previously (Kim, 1981). This is a colorimetric procedure of measuring the amount of dye released from the Cibachron Blue F3GA-amylose complex upon hydrolysis of the $\alpha 1-4$ bonds of the amylose by the action of $\alpha$-amylase.

Tissue amylase was extracted by an extensive homogenization of lobules in phosphate buffered saline (PBS). An aliquot was removed from the homogenate, centrifuged at $25,000 \mathrm{xg}$ for 10 minutes and the supernatant was used for $\alpha$-amylase activity determination. The medium samples collected at various times during incubation and the tissue samples at the end of incubation were assayed for $\alpha$-amylase activity.

The cumulative amount of $\alpha$-amylase activity released into the incubation medium was followed with time. The cumulative amount in the medium and the amount of activity remaining in the tissue at the end of incubation constituted the total enzyme activity. Percentage release of $\alpha$-amylase was calculated from the enzyme activity released into the medium and the total activity. The DNA contents of the tissue were determined according to Burton (1958).

\section{Morphological Observations}

The glandular lobules were prepared for morphological observations at various time periods during the incubation. These lobules were fixed in the fixative containing paraformaldehyde and glutaraldehyde, post-fixed in osmium and processed for viewing in the light and electron microscope as described previously (Kim, 1981; $\mathrm{Kim}$, et al., 1980). Thick sections $(1 \mu \mathrm{m})$, after staining with toluidine blue, were used for light microscopy. The blocks were further trimmed and thin sections (about $700 \mathrm{~A}$ ) were cut for viewing in a Hitachi 11c electron microscope.

\section{RESULTS}

\section{The $\alpha$-amylase content in parotid glands}

The cellular contents of $\alpha$-amylase in parotid glands in these rats do not appear to change between the ages of 2 and 24 months. The level of $\alpha$-amylase activity in the glands, compared based on the DNA content, is not significantly different at these ages (Table 1). However, the DNA content/mg tissue of the gland is significantly different at these two ages (Table 1), and this might reflect the age-related increase in the amount of glandular tissue contents.

\section{The IPR stimulated release of $\alpha$-amylase}

The lobules prepared from the glands of both age groups release $\alpha$-amylase spontaneously at a fairly stable rate for up to 4 hours of incubation in MEM, at $37^{\circ} \mathrm{C}$ (unpublished observation). The amylase release is greatly stimulated upon addition of IPR in the medium, and this stimulated release is dependent upon the concentrations of the 
TABLE 1. LeVELS OF $\alpha$-AMYLASE ACTIVITY AND CONTENTS OF DNA IN PAROTID GLANDS

\begin{tabular}{cccccc}
\hline $\begin{array}{c}\text { Age } \\
\text { Mos. }\end{array}$ & $\begin{array}{c}\text { No. of } \\
\text { Rats }\end{array}$ & $\begin{array}{c}\text { No. of } \\
\text { Samples }\end{array}$ & $\frac{\text { D.U. }^{\mathrm{a}}}{\text { MG Tissue }} \pm$ S.E. $\times 10^{3}$ & $\frac{\text { D.U. }^{\mathrm{a}}}{\text { MG DNA }} \pm$ S.E. $\times 10^{\mathrm{b}}$ & $\frac{\mu G \text { DNA }}{\text { MG Tissue }^{\prime}}$ \\
\hline 2 & 4 & 16 & $152.2 \pm 7.8$ & $40.3 \pm 2.8^{\mathrm{b}}$ & $3.86 \pm 0.09^{\mathrm{c}}$ \\
24 & 3 & 14 & $151.0 \pm 8.9$ & $47.7 \pm 3.0^{\mathrm{b}}$ & $3.19 \pm 0.08^{\mathrm{c}}$ \\
\hline
\end{tabular}

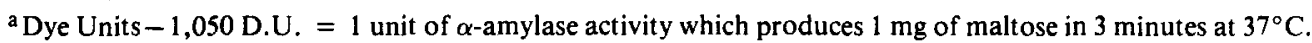

${ }^{\mathrm{b}}$ Not significantly different $(0.05<P<0.1)$

'Significantly different $(P<0.001)$

secretogogue (Fig. 1). The maximum release of $\alpha$-amylase is obtained with $10^{-5} \mathrm{M}$ IPR in the medium, and, therefore, this concentration was used throughout the study in comparing the stimulated release of $\alpha$-amylase.

There is no significant difference in the IPR-stimulated release of $\alpha$-amylase by the lobules from 2 and 24 month old rats (Fig. 2). The lobules from the glands of these rats of both ages release about the same proportions of the total amylase at about the same rate

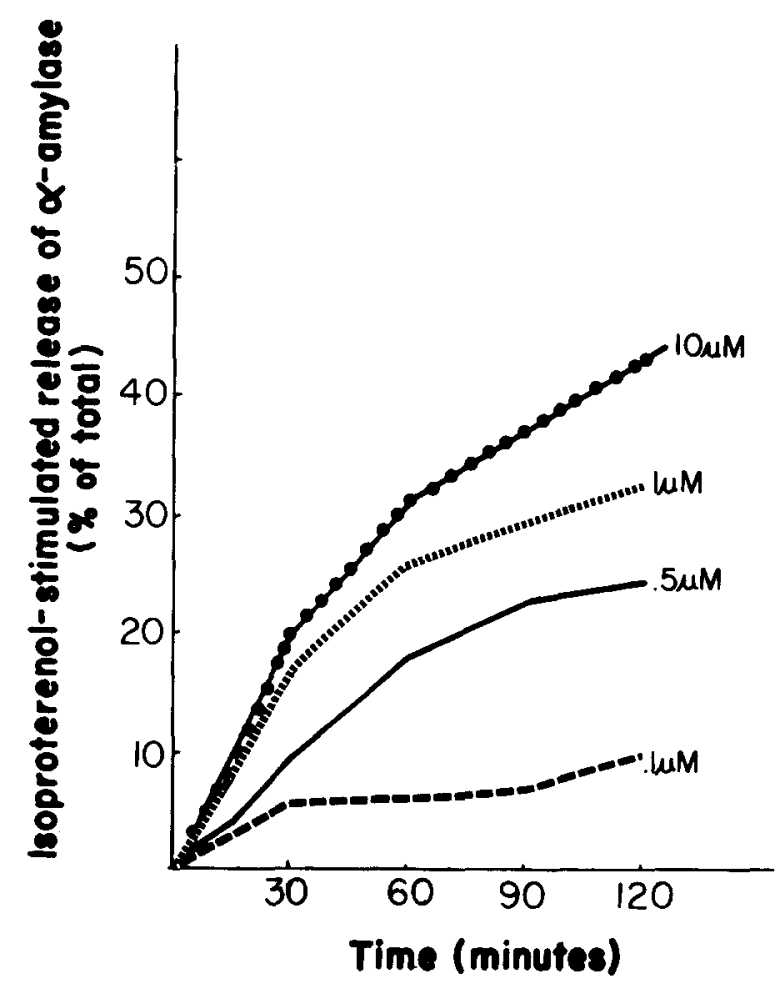

FIG. 1. Dependence of $\alpha$-amylase release from parotid lobules on the concentration of isoproterenol. Parotid lobules from 2-month-old rats were incubated in the presence of varying concentrations of the secretogogue. The percentage of $\alpha$-amylase released into the medium was calculated for this figure, as well as the other ones, as described in the Methods. 


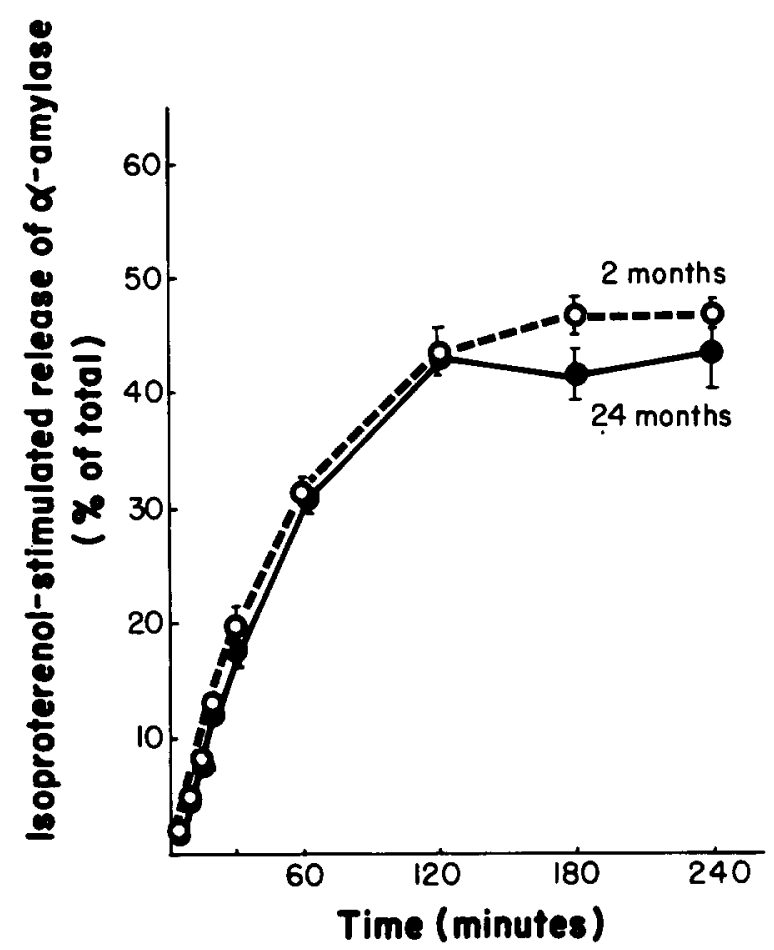

FIG. 2. Comparisons of the release profile of $\alpha$-amylase from the parotid lobules of 2 and 24 months old rats upon incubation with isoproterenol in the concentration of $10^{-5} \mathrm{M}$ in the medium. Values represent means \pm S.D. of 3 experiments.

upon incubation with IPR (Fig. 2). The release of amylase seems to occur in 2 phases. The rate of release increases rapidly in the initial phase of incubation with IPR, reaching the highest rate at $\mathbf{2 0}$ minutes in both groups (Figs. 3a and $\mathbf{3 b}$ ). After this phase, the rate of release declines gradually and this decline is paralleled in both age groups.

The effects of $\beta$-blocker on the IPR-stimulated release of $\alpha$-amylase

The release of $\alpha$-amylase is inhibited by propranolol in both age groups when the lobules are preincubated with the $\beta$-blocker before stimulating with IPR (Fig. 4). Following preincubation of the lobules in the presence of $10^{-5} \mathrm{M}$ propranolol, the IPR-stimulated release of $\alpha$-amylase is initially blocked almost completely in both groups. The inhibitory effect of propranolol decreases with time. However, the amylase release at the end of a 1 hour incubation with IPR is still inhibited by about 90 percent of the level released by the control lobules in both age groups.

\section{Morphological appearances of the incubated lobules}

The morphological changes which occur in the lobules during the incubation with IPR are similar in cases of the young and old rats. As illustrated with the lobules of 24 month old rats in Figs. 5-8, the acini become devoid of secretory granules within 30 minutes of 


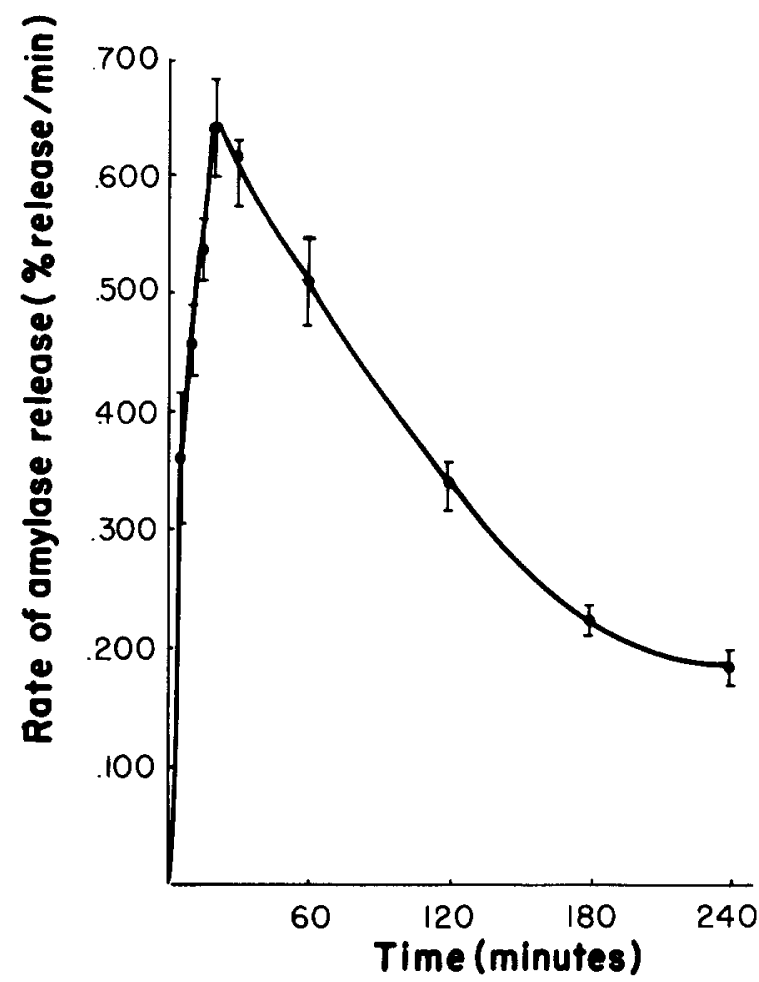

FIG. 3a. The rate of release of $\alpha$-amylase at various time periods during incubation of the lobules from 2 month old rats in the presence of isoproterenol $\left(10^{-3} \mathrm{M}\right)$. Values represent means \pm S.D. of 4-8 samples.

incubation. In the lobules incubated for 10 minutes with the secretogogue, the numbers of the secretory granules are reduced while the lumens of the acini are widened (Fig. 5). These changes are more pronounced at 20 minutes (Fig. 6). At the end of $\mathbf{3 0}$ minute incubation (Fig. 7), secretory granules are absent in most of the acinar cells. On the other hand, in the lobules incubated for 30 minutes in the medium without IPR (Fig. 8), the cells retain secretory granules and these lobules are similar in appearance to the unincubated lobules (not shown). When viewed in the electron microscope (Fig. 9), the widened lumens are bound by the acinar cell membranes which protrude deep into the cytoplasm in many places. The luminal space reveals amorphous substances.

\section{DISCUSSION}

The results of our in vitro release experiments in this study indicate that the ability of the parotid gland cells to secrete proteins upon stimulation by secretogogues does not change with age. This is evidenced by the similarities shown by the lobules of 2 and 24 month old rats in releasing $\alpha$-amylase upon incubation with IPR. The isolated lobules of these two age rats release about the same proportion of tissue amylase at about the same rate upon incubation with the secretogogue. Similar results have been reported previously 


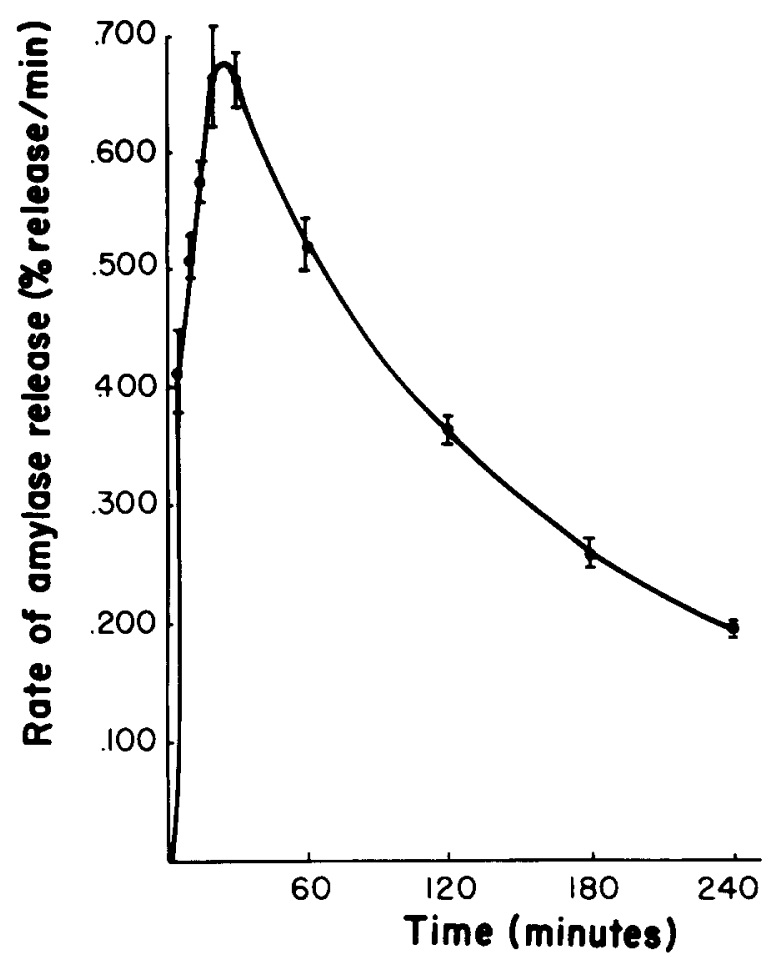

Fig. 3b. The rate of release of $\alpha$-amylase at various time periods upon incubation of the lobules from 24 month old rats in the presence of isoproterenol $\left(10^{-5} \mathrm{M}\right)$. Values represent means \pm S.D. of $4-8$ samples.

by others using enzymatically dispersed cell aggregates from rat parotid glands of varying ages (Ito, et al., 1981).

The IPR-stimulated release of amylase, observed in this study, is mediated by $\beta$-adrenergic receptors and occurs by the process of exocytosis as demonstrated by the study with propranolol and morphological observations of the incubated lobules, respectively. The IPR-stimulated release of amylase is inhibited by preincubating the lobules in the presence of this $\beta$-blocking agent and the effect of it reduces with time in both age groups. It has been shown that propranolol binds exclusively to the $\beta$-receptors (Levitzki, et al., 1974) and that the bound propranolol becomes displaced by IPR with time in a concentration dependent manner (Levitzki, et al., 1974; Atlas, et al., 1974).

The discharge of secretory granule contents occurs by the fusion of the granule membranes with the cell membranes at the luminal surface as shown morphologically in parotid glands of young rats (Amsterdam, et al., 1969; Lillie and Han, 1973). This is the case also in the glands of older rats as demonstrated in this study. During the incubation with IPR, the number of secretory granules decreases as the lumens widen in the parotid lobules. The festooned appearance of the lumen in the incubated lobules probably resulted from the fusion of the granules with the cell membrane during exocytosis. Thus, the IPR-stim. ulated release of $\alpha$-amylase from the lobules of young and old rats represents the true secretory activity of the gland and not the leakage of the enzyme during incubation. 


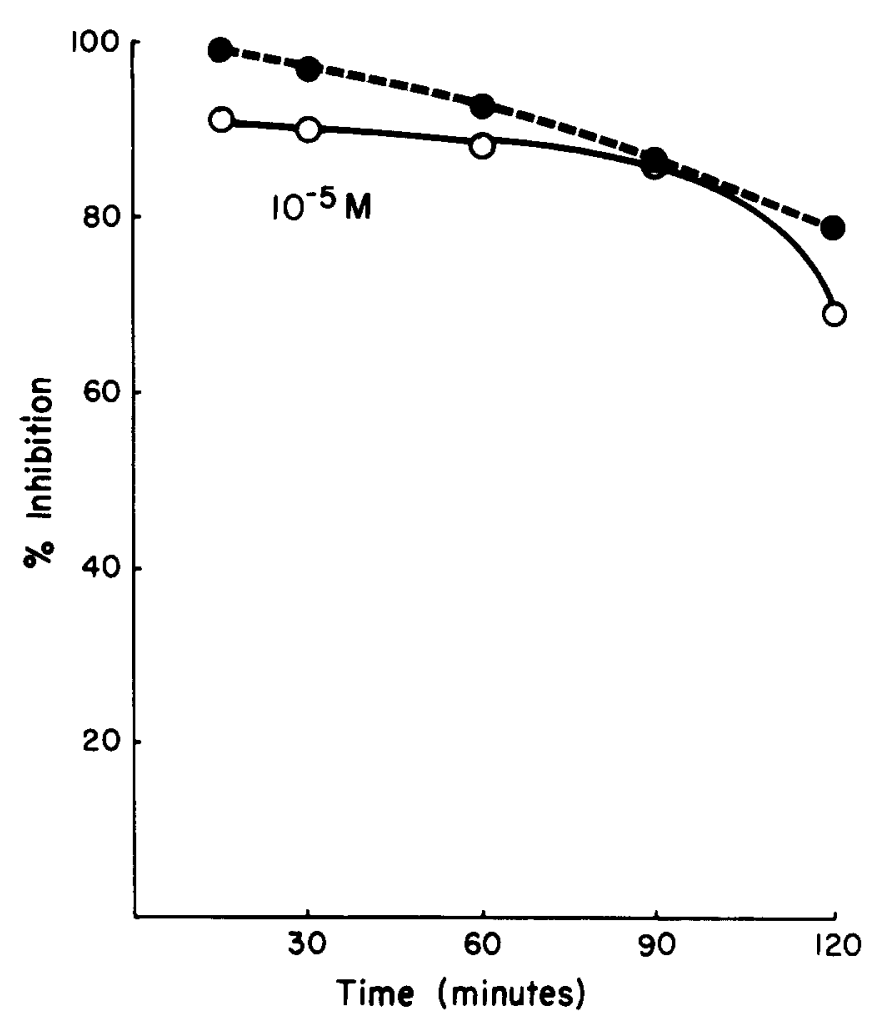

FIG. 4. The effect of a $\beta$-adrenergic blocker on the isoproterenolstimulated release of amylase from the lobules of $2\left(-^{-}\right)$and $24\left(-0_{-}\right)$ month old rats. The secretogogue-stimulated release of amylase is inhibited nearly completely by preincubating with propranolol $\left(10^{-5} \mathrm{M}\right)$ in both groups.

Then, it appears that the age-related decline in protein synthesis in this gland (Kim, et al., 1980; 1981; 1982; Kim, 1981) occurs unrelated to the reduction in the ability of the secretory cells to release proteins. It is possible, however, that the reduced level of protein synthesis in old rats is related to the general decline in the secretory activity of the gland, presumably due to the reduced level of digestive activity with age. Thus, the secretory proteins which are stored in cells for prolonged periods of time might have an inhibitory effect on the synthesis of more proteins.

In fact, there is no significant difference in the cellular level of $\alpha$-amylase activity in the glands of 2 and 24 month old rats, despite the reduction in the level of protein synthesis in the older rats. Since this enzyme makes up a large proportion of the secretory protein produced by this gland (Schramm, 1968), the results indicate that the cellular level of secretory proteins does not change with age. This is the case regardless of whether the comparison is made based on the wet weight or the DNA content of the gland. The reduction in the amount of DNA per unit weight of the gland in the older rats probably reflects the increase in the amount of nonsecretory tissues, such as fat, fibrous connective tissue and others during aging. The age-related increase in the amount of fat and other supportive tissues 

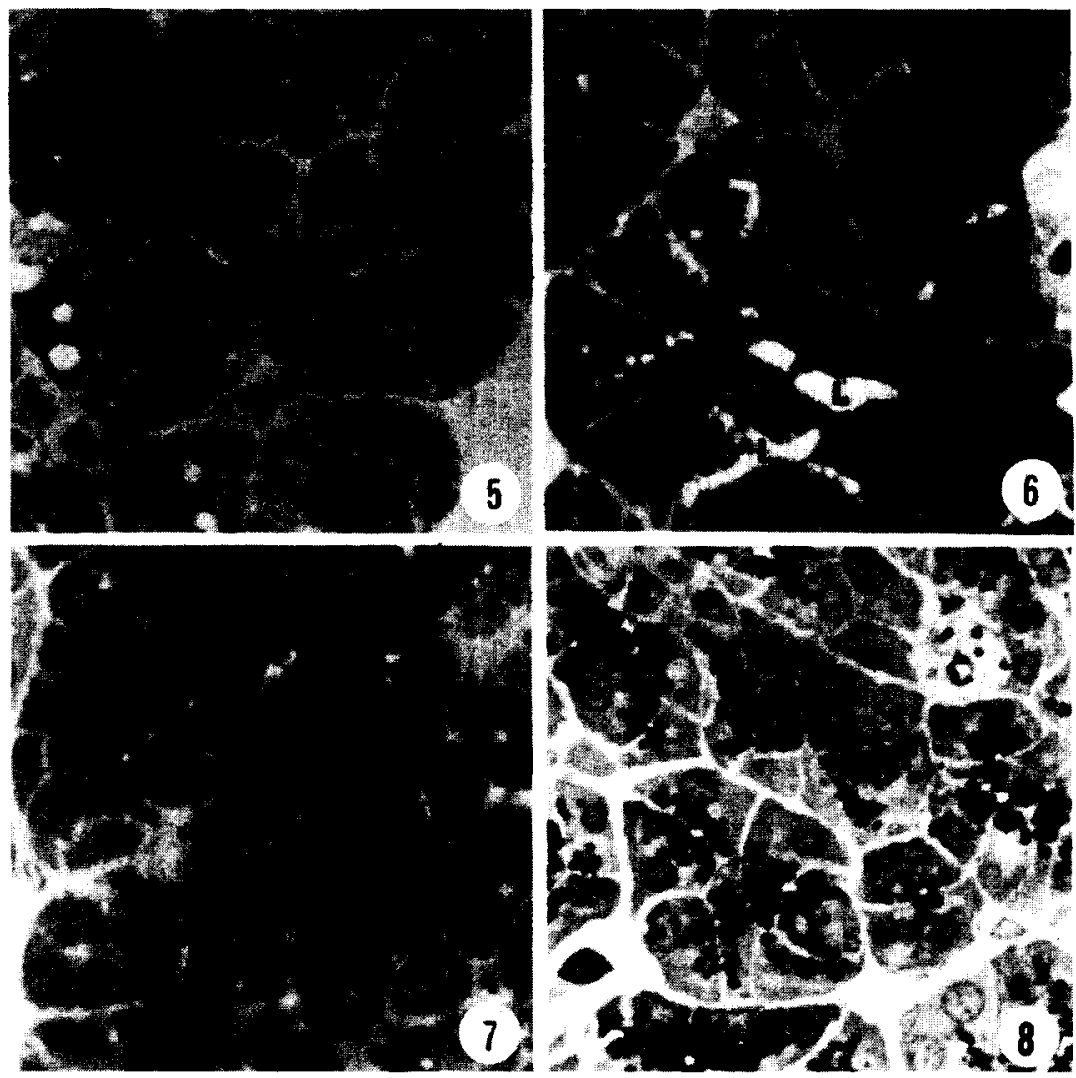

Figs. 5-8. Light micrographs showing parotid lobules from 24 month old rats incubated in the medium containing $10^{-5}$ MIPR for 10 (Fig. 5), 20 (Fig. 6) and 30 (Fig. 7) minutes. The lobule shown in Fig. 8 was incubated for 30 minutes in the medium without IPR as a control. With increasing time, the number of secretory granules decreases while the lumen (L) of the acini widens. After incubating for $\mathbf{3 0}$ minutes, the acinar cells are devoid of secretory granules. On the other hand, the lobules incubated without IPR retain most of the secretory granules even after a 30 minute incubation $(\times 1,000)$.

has been reported to occur in parotid glands and other salivary glands (Andrew, 1949; Bogart, 1970).

Previously, we have reported that the cellular level of $\alpha$-amylase declines with age in parotid glands of rats (Kim, 1981). However, these rats, obtained from the aging colony maintained at Charles River Breeding Laboratories in Wilmington, Massachusetts, showed positive titers for sialodacryoadenitis viruses. Therefore, the reduced level of amylase in the gland of these rats could have reflected the clinical manifestations of this salivary gland disease.

\section{SUMMARY}

In order to determine whether there are changes in the cellular secretory activity during aging, the ability of parotid acinar cells to release $\alpha$-amylase has been examined. This was done by comparing the release profiles of the enzyme from the glandular lobules of 2 and 


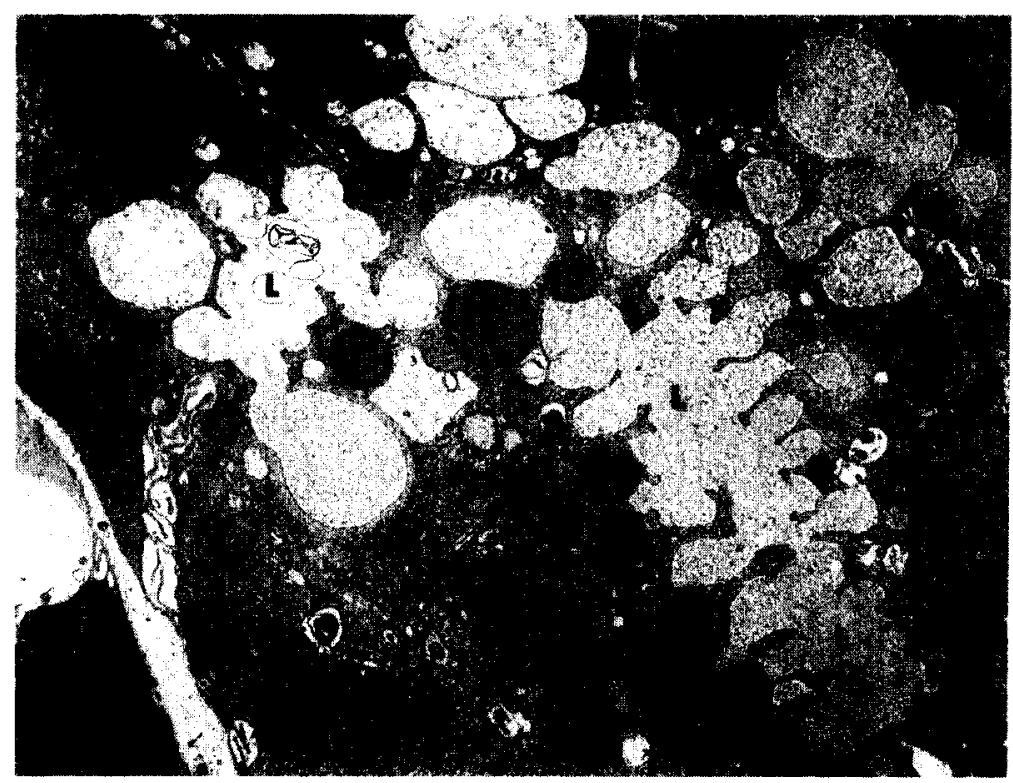

FIG. 9. Electron micrograph of a lobule incubated for 20 minutes in the presence of IPR $\left(10^{-5} \mathrm{M}\right)$ showing widened lumens (L) of the acinus. The festooned appearance of the lumen probably resulted from the fusion of the secretory granules with the cell membrane. The amorphous substance present in the luminal space is likely to be the secreted contents of the granules. Lipofusion granules $(G)$ which are present commonly in the glands of old rats are indicated $(\times 7,000)$.

24 month old rats upon stimulation by incubating in the presence of a secretogogue, isoproterenol (IPR). The lobules from these two age rats release about the same proportions of the tissue $\alpha$-amylase at about the same rate upon incubation with IPR $\left(10^{-5} \mathrm{M}\right)$. The IPR-stimulated release of the enzyme is inhibited similarly in these age groups by preincubating the lobules with a $\beta$-blocker, propranolol $\left(10^{-5} \mathrm{M}\right)$. Furthermore, the release of the secretory products from the glands of the older rats seems to occur by means of exocytosis, as is the case in young rats. These results indicate that the ability of the cells to release secretory products through the stimulation of $\beta$-receptors remains unchanged during aging in parotid glands of the rat.

Acknowledgements - Authors thank Virginia Hartog for assistance in the experiments. This work was supported by the Veterans Administration and by Grant AG 00944 from the National Institute on Aging.

\section{REFERENCES}

Amsterdam, A. Ohad, I. and Schramm, M. (1969) J. Cell Biol., 41, 753.

Andrew, W. (1949) Am. J. Anat., 85, 157.

Atlas, D., Steer, M.L., and Levitzki, A. (1974) Proc. Nat. Acad. Sci., 71, 4246.

Babad, H., Ben-zvi, R., Bdolah, A., and Schramm, M. (1967) Eur. J. Biochem., 1, 96.

Bertram, U. (1967) Acta. Odont. Scand., 25 Suppl.

Bdolah, A., Ben-zvi, R., and Schramm, M. (1964) Arch. Biochem. Biophys., 104, 58.

Bdolah, A., and Schramm, (1965) Biochem. Biophys. Comm., 18, 452.

Bogart, B.I. (1970) J. Morph., 130, 337. 
Burton, K. (1958) Biochem. J., 62, 315.

Butcher, F.R. and Goldman, J.A. (1974) J. Cell Biol., 60, 519.

Butcher, F.R., Goldman, R.H. and Namerovski, M. (1975) Biochim. Biophys. Acta., 392, 82.

Castle, J.D., Jamieson, J.D. and Palade, G.E. (1972) J. Cell Biol., 53, 290.

Chilla, R., Niemann, H., Arglebe, C. and Domagk, G.F. (1974) J. Oto-Rhino-Laryngol $36,372$.

Grand, R.J., and Gross, P.R. (1969) J. Biol. Chem., 244, 5608.

Ito, H., Baum, B.J., and Roth, G.S. (1981) Mech. Ageing Devel., 15, 177.

KIM, S.K. (1981) J. Den. Res., 60, 738.

Kim, S.K., Calkins, D.W., Weinhold, P.A. and HaN, S.S. (1982) Mech. Aging Develop., 18, 239.

Kim, S.K., Weinhold, P.A., Calkins, D.W. and Hartog, V.W. (1981) Exp. Gerontol., 16, 91.

KIM, S.K., WeInhold, P.A., HaN, S.S. and WAGNeR, D.J. (1980) Exp. Gerontol. 15, 77.

KuseK, J.C. (1979) Biochim. Biophys. Acta, 583, 295.

Levitzki, A., Atlas, D., and Steer, M.L. (1974) Proc. Nat. Acad. Sci. 71, 2773.

Lillie, J.H. and HaN, S.S. (1973) J. Cell Biol., 59, 708.

Malamud, D. (1972) Biochim. Biophys. Acta, 279, 373.

Meyer, J., Golden, J.S., Steiner, N. and Necheles, H. (1937) Amer. J. Physiol., 119, 600.

Meyer, J. and Necheles, H. (1940) Amer. Med. Assoc., 115, 2050.

Nelsen, T.E. and Stouffer, J.E. (1972) Biochem. Biophys. Res., 48, 480.

SChNeYer, C.A., and HAll, H.D. (1967) Secretory Mechanisms of Salivary Glands. (Edited by L.H. SCHENEYER, and C.A. Schneyer), p. 155. Acad. Press, New York.

Schramm, M. (1968) Biochim. Biophys. Acta, 165, 546.

Sreebny, L.M., Johnson, D.A. and Robinovitch, M.R. (1971) J. Biol. Chem., 246, 3879. 